\title{
Influence of Adhesive Bonded Surface Treatment of Alloy Alcu4mg and Increased Environ- mental Temperature on Adhesive Bond Strength
}

Jan Cidlina, Miroslav Müller

Faculty of Engineering, Czech University of Life Sciences Prague. Czech Republic. E-mail: cidlina@tf.czu.cz, muller@tf.czu.cz.

For the creation of the bond the treatment of the adhesive bonded surface is essential. The second important factor is the temperature of the environment to which the adhesive bond is exposed. It is a way of a degradation of adhesive bonds. The aim of the research was to evaluate the effect of adhesive bonded surface treatment of alloy AlCu4Mg and increased environmental temperature on a strength of adhesive bonds using two-component epoxies used in the transportation industry. As a bonding material $\mathrm{AlCu} 4 \mathrm{Mg}$ was used, whose surface was in the first series mechanically and chemically treated. In the second series tested specimens were without the surface treatment. A destructive testing was conducted at a laboratory temperature $22 \pm 2{ }^{\circ} \mathrm{C}$ and at increased temperatures, i.e. 40, 60 and $80 \pm 2{ }^{\circ} \mathrm{C}$. At a mutual comparison of the mechanical treatment and the chemical treatment of the adhesive bonded surface with un-treated surface, the tensile lap-shear strength increased by an average of $57.24 \pm$ $18.52 \%$. The results show that there is a difference in the tensile lap-shear strength between the test temperatures in the interval $20-80{ }^{\circ} \mathrm{C}$, the decrease was up to $88 \%$.

Keywords: Adhesive bond, two-component epoxy adhesives, testing

\section{Acknowledgement}

This paper has been done when solving the grant IGA TF (No.: 2015:31140/1312/3106).

\section{References}

[1] MÜLLER, M., VALÁŠEK, P. (2012). Degradation medium of agrokomplex - adhesive bonded joints interaction. In: Research in Agricultural Engineering, Vol. 58, pp. 83-91.

[2] MESSLER, R., W. (2004). Joining of materials and structures from pragmatic process to enabling technology. Burlington: Elsevier, 816 pp.

[3] MÜLLER, M. (2013). Research of Liquid Contaminants Influence on Adhesive Bond Strength Applied in Agricultural Machine Construction. In: Agronomy Research, Vol.11, pp. 147-154.

[4] RUDAWSKA, A. (2014). Selected aspects of the effect of mechanical treatment on surface roughness and adhesive joint strength of steel sheets. In: International Journal of Adhesion and Adhesives, Vol. 50, pp. 235-243.

[5] CIDLINA, J., MÜLLER, M., VALÁŠEK, P. (2014). Evaluation of Adhesive Bond Strength Depending on Degradation Type and Time. In: Manufacturing Technology, Vol. 14, No. 1, pp. 8-12.

[6] PAREIRA, A.M., FERREIRA, J.M., ANTUNES, F.V., BARTOLO, P.J. (2010). Analysis of manufacturing parameters on the shear strength of aluminium adhesive single-lap joints. In: Journal of Materials Processing Technology, Vol. 210, pp. 610-617.

[7] RAMAZAN, K., MEHMET, S., BEKIR, Y. (2008). Influence of adhesive thickness and filler content on the mechanical performance of aluminium single-lap joints bonded with aluminium powder filled epoxy adhesive. In: Journal of materials processing technology, Vol. 205. pp. 183-189.

[8] VALÁŠEK, P. (2014). Long-term degradation of composites exposed to liquid environments in agriculture. In: Scientia Agriculturae Bohemica, Vol. 3, No. 1, pp 187-192.

[9] MÜLLER, M. (2011). Influence of Surface Integrity on Bonding Process. In: Research in Agricultural Engineering, Vol. 57, pp. 153-162.

[10] ADAMS, R. D., COMYN, J., WAKE, W. C. (1997). Structural adhesive joints in engineering. 2nd ed. Chapman \& Hall, London. 360 pp.

[11] HABENICHT, G. (2002). Kleben: Gundlagen, Technologien, Anwendung. Berlin: Springer. 921 pp.

[12] HARRIS, A. F., BEEVERS, A. (1999). The effects of grit-blasting on surface properties for adhesion. In: International Journal of Adhesion \& Adhesives, Vol. 19, No. 6, p. 445-452.

[13] SHAHID, M., HASHIM, S. A. (2002). Effect of surface roughness on the strength of cleavage joints. In: International Journal of Adhesion \& Adhesives, Vol. 22, No.3, p. 235-244. 
[14] GRITCHLOW, G.W., BREWIS, D.M. (1995). Influence of surface macroroughness on the durability of epoxidealuminium joints. In: International Journal of Adhesion \& Adhesives, Vol. 15, No. 3, p. 173-176.

[15] SARGENT, J.P. (1994). Adherend surface morphology and its influence on the peel strength of adhesive joints bonded with modified phenolic and epoxy structural adhesives. In: International Journal of Adhesion \& Adhesives, Vol. 14, No. 1, p. 21-30.

[16] NOVÁK, M. (2012). Surfaces with high precision of roughness after grinding. In: Manufacturing technology, Vol. 12 , pp. $66-70$.

[17] NOVÁK, M. (2011). Surface quality of hardened steels after grinding. In: Manufacturing technology, Vol. 11, pp.55-59.

[18] HRICOVA, J. (2014). Environmentally conscious manufacturing: the effect of metalworking fluid in high speed machining. In: Key engineering materials. Vol. 581, pp. 89-94.

[19] CROCOMBE, A. D. (1997). Durability modelling concepts and tools for the cohesive environmental degradation of bonded structures. In: International Journal of Adhesion \& Adhesives, Vol. 17, No. 3, p. 229-238.

[20] KINLOCH, A. J., OSIYEMI, S. O. (1993). Predicting the fatigue life of adhesively-bonded joints. In: Journal of adhesion, Vol. 43, No. 12, p. 79-90.

[21] MÜLLER, M., HERÁK, D. (2013). Application possibilities of adhesive bonds - Europe, Indonesia. In: Scientia Agriculturae Bohemica, Vol. 44, pp. 167-171.

[22] MÜLLER, M., HERÁK, D., VALÁŠEK, P. (2013). Degradation limits of bonding technology depending on destinations Europe, Indonesia. In: Tehnicki Vjesnik- Technical Gazette, Vol. 20, pp. 571-575.

[23] DOBRÁNSKÝ, J., BARON, P., KOČIŠKO, M., BĚHÁLEK, L, VOJNOVÁ, E. (2015). Soloving depressions formed during production of plastic molding. In: Metalurgija, Vol. 54, No. 3, 496-498.

[24] DOBRÁNSKÝ, J., BARON, P., KOČIŠKO, M., VOJNOVÁ, E (2014). Monitoring of the influence of moisture content in thermoplastic granulate on rheological properties of material. In: Applied Mechanics and Materials. Vol. 616, 207-215.

[25] HU, P., HAN, X. LI, W.D., LI, L., SHAO, Q. (2013). Research on the static strength performace of adhesive single lap joints subjected to extreme temperature environment for automotive industry. In: International Journal of Adhesion and Adhesives. Vol. 41, pp. 119-126.

[26] MÜLLER, M., RUŽBARSKÝ, J., VALÁŠEK, P. (2014). Degradation process in area of connecting metal sheets by adhesive bonding technology in agrocomplex. In: Applied Mechanics and Materials. Vol. 616, pp. 52-60.

[27] ŤAVODOVA, M. (2013). The surface quality of materials after cutting by abrasive water jet evaluated by selected methods. In: Manufacturing technology. Vol. 13, pp. 236-241.

[28] PROLONGO, S.C., URENA, A. (2009). Effect of surface pre-treatment on the adhesive strength of epoxy-aluminium joints. International Journal of Adhesion \& Adhesives. Vol. 29, p. 23-31.

[29] BAKER, A.A., CHESTER, R.J. (1992). Minimum surface treatments for adhesively bonded repairs. In: International Journal of Adhesion \& Adhesives, Vol. 12, No. 2, p. 73-78.

[30] ELBING, F., ANAGREH, N., DORM, L. UHLMANN, E. (2003). Dry ice blasting as pretreatment of aluminium surfaces to improve the adhesive strength of aluminium bonding joints. In: International Journal of Adhesion \& Adhesives, Vol. 23, p. 69-79.

[31] BORSELLINO, C., DI BELLA, G., RUISI, V.F. (2009). Adhesive joining of aluminium AA6082: the effects of resin and surface treatment. In: International Journal of Adhesion \& Adhesives, Vol. 29, p. 36-44.

[32] HARRIS, A.F., BEEVERS, A. (1999). The effects of grit-blasting on surface properties for adhesion. In: International Journal of Adhesion \& Adhesives, Vol. 19, p. 1445-452.

[33] GRANT, L. D. R., ADAMS, R.D, DA SILVA, L.F.M (2009). Experimental and numerical analysis of single-lap joints for the automotive industry. In: International Journal of Adhesion \& Adhesives, Vol. 4, pp. 405-413. 